\title{
Global Value Chains: Government Policies for Enhancing the Role of Small and Medium Enterprises in Global Value Chains - A Case Study of Slovenia
}

\author{
SABINA KOLEŠA \\ Ministry of Economic Development and Technology, Slovenia \\ sabina.kolesa1@siol.net
}

The purpose of our research is to identify key factors and government policies supporting small and medium enterprises' (SMES) successful integration into global value chains (Gvcs). Our main research questions are: How are economies involved in Gvcs and does integration depend on the size of a country? What role do governments play in fostering upgrading the position in order to best derive benefits from Gvcs? How is Slovenia seizing the opportunities of GVc integration? Our research shows increased engagement by all the selected countries in international production linkages in the period from 1995 to 2011, with participation index correlated with the size of a country (small economies being more integrated). A key finding is that a 'whole of the chain' approach is needed, and governments should implement policies and targeted support programmes linked to innovation, knowledge-based assets, etc. in order to best respond to the reality of more interconnected economies and draw the greatest benefits from engagement in Gvcs. A case study of Slovenia shows the economy has been rapidly integrating into Gvcs; however, we submit recommendations to policymakers on the subject of policies as a means to further promote the integration of SMEs and upgrade into GVCS.

Key words: global value chains, government policy, small and medium enterprise https://doi.org/10.26493/1854-4231.13.49-70

\section{Introduction}

World trade is undergoing major changes. Over the last decades, the progressive liberalization of cross-border transactions and advances in information, communication and transport technologies have provided firms with greater incentives to fragment the production process and to geographically delocalize them - in order to increase efficiency and lower costs. The complex and interconnected produc- 
tion process that goods and services undergo from conception and design through production, marketing, distribution, and support to the final consumer is referred to as a global value chain (GVC) or an international production network (OECD 2013). With the growth of GVCs, economies are increasingly specialised in specific activities (processed with value added in the multiple countries that are part of the chain) rather than in industries. International trade involves extensive flows of intermediate goods and services. Today more than half of world-manufactured imports are intermediate goods - primary parts and components and semi-finished products (Backer and Miroudot 2013; Cusolito, Safadi, and Taglioni 2016). More than $70 \%$ of world services imports are intermediate services, and international competition increasingly plays out at the level of activities within industries (Feenstra 1998).

The high level of interconnectedness poses a variety of challenges and benefits for, and risks to countries participating in GVCs, with implications for many policy areas (trade, economic, development, education, etc.). The integration of companies into GVcs is becoming an increasingly important determinant of export performance and competitiveness. We argue that trade in tasks/intermediate goods (or 'vertical specialisation' i.e., import content of exports) offers new options to small countries and small and medium size enterprises (SMES), due to the possibility to focus on a single segment of the industrial process and to reach cost competitiveness without having to develop fully fledged industries (Elms and Low 2013).

The goal of our research is to identify the factors important to the integration and upgrading of the position in GVCs as well as the policies' actions to encourage the integration of small and medium enterprises in order to derive the best benefits from Gvcs for the economy.

Our main research questions are: How are economies involved in GVCS and does integration depend on the size of a country? What role do governments play in fostering upgrading the position in order to best derive benefits from Gvcs? How is Slovenia, a small open economy, seizing the opportunities of GVc integration? A combination of methods is used in the study, namely desktop analysis (analysis of primary and secondary data) with a combination of quantitative and qualitative analysis. For Slovenia's case study, a participant observation method is also applied.

At the beginning, reference is made to the economic theories in relation to global value chains, small and medium size enterprise integration into Gvcs, and related policy issues for upgrading. 
We focus on SMES, as there is strong empirical evidence that SMES are socially and economically important as sources of employment and income. In developed and developing countries they account for the absolute majority of companies, generating more than half of formal jobs $(60 \%)$; they are higher than their proportion in added value (50\%-60\% on average), but their contribution to overall exports is significantly lower ${ }^{1}$ (between $20 \%$ and $40 \%$ ) (UNCTAD 2007; OECD $2017 \mathrm{~b}$ ). In 2014, in the $\mathrm{E} U$ for example, smes represented $99.8 \%$ of all enterprises, provided around 90 million jobs, and generated $58 \%$ of the value added. In Slovenia $99.8 \%$ of all companies are SMES, providing about $63 \%$ of the value added and nearly $73 \%$ of employment (European Commission 2015).

Then, we analyse the participation changes/trends of selected countries in the GVCS in the period from 1995 to 2011 (the latest available data in the oECD-WTO Tiva database). ${ }^{2}$ We focus on the major economies: the EU integration, USA, Canada, China, Japan, and within the EU on five large (Germany, France, United Kingdom, Spain, and Poland) and seven small economies (Austria, Belgium, Ireland, Czech Republic, Slovakia, and Slovenia). We argue that integration in GVcs depends on the size of the country.

The data used for the analysis is taken from the World Input Output Database (WIOD) and the OECD-wto tiva database of trade flows in value-added terms (Tiva) (that in our opinion provides a more complete picture of how country exports are interwoven with others and how value is distributed throughout value chains rather than trade measured in gross terms). In order to enhance the importance of the GVC for small open economies, we apply a case study analysis of Slovenia. We analyse statistical data on GVC integration (овCD-Wто тіva database and relevant studies) and government policies/activities/instruments in place to support SMEs integration and upgrading into Gvcs (based on information published on government institution web pages and applied participant observation method). Based on review of the literature, analyses made, a case study, and a synthesis of findings, we submit recommendations to policymakers on the subject of policies as a means to further promote the integration of SMES and their upgrade into GVCS.

\section{Review of the Related Literature}

In the literature, the debate on global value chains, value added, and trade and their policy relevance in terms of countries' strategies is not a new phenomenon. Mainly, the literature on GVcs has focused on organizational issues of Gvcs and their relationship to interna- 
tional trade patterns i.e., allocation of ownership rights along the value chain, specialization patterns of stages across countries, and the effects of trade costs on multiplied trade flows in the presence of GvCS (Antras and Chor 2013; Baldwin and Venables 2013; Consolito, Safadi, and Tagliani 2016; Costinot, Vogel, and Wang 2013; Yi 2003).

However, the work on the effects of GVc participation on domestic outcomes has evolved quickly. Studies have suggested that any analysis with respect to gains from trade should be based on net value added by trade (Porter 1985). Likewise, comparative advantage, which was typically expressed in terms of products/industries according to the earlier trade models, now requires a basis on activities and tasks (Gereffi 1999).

The literature on Gvcs uses the measure of 'vertical specialisation' (defined as the import content of exports) to gauge a country's competitiveness in Gvcs. Studies have estimated vertical specialisation separately for intermediate and finished products to arrive at the relative competitive position of a country in the value chains (Banga 2013, 12).

A wide literature has developed over the last decade on the ingredients of successful upgrading by firms, and part of the literature is particularly concerned with the question of what role governments should play in fostering upgrading. For policymaking, understanding governance structures is important - in particular, to assess how policies can have an impact on firms and the location of activities. At any point in the chain, the production process is defined by a set of parameters. Value added depends upon tasks or business functions. Production is at the bottom and high value added is found upstream (research and development, design, logistics: purchase) or downstream (logistics: distribution, marketing, services). Enterprises looking to upgrade have different options depending on their capacity, e.g. technology, human capital, etc. Trade in tasks makes it easier to diversify, as different products may require executing similar tasks in the value chain. On the other hand, even small margins in production can be compensated by high volumes and can be a better option than diversifying. As stated by Gereffi (1999), moving in and up into GVCs requires fitting into existing corporate strategies and establishing close links with the lead firms. This leads us to governance structures and the actors that control the activities.

An important difference emphasized in the literature is between 'producer-driven' (high tech sectors) and 'buyer-driven' chains (low tech) (Gereffi 1999). The analysis can help policymakers identify the firms and actors that control and coordinate activities. In the 
TABle 1 The Main Differences between Producer and Buyer-Driven Gvcs

\begin{tabular}{lll}
\hline Item & Producer-driven Gvcs & Buyer-driven Gvcs \\
\hline Controlling type of capital & Industrial & Commercial \\
Capital/tech. intensity & High & Low \\
Labour characteristics & Skilled/high wage & Unskilled/low wage \\
Controlling firm & Manufacturer & Retailer \\
Production integration & Vertical/bureaucratic & Horizontal/networked \\
Control & Internalized/hierarchical & Externalized/market \\
Contracting/outsourcing & Moderate and increasing & High \\
Suppliers provide & Components & Finished goods \\
Examples & Automobiles, computers, & Clothing, footwear, toys, \\
& aircraft, electrical & consumer electronics \\
& machinery & \\
\hline
\end{tabular}

Notes Adapted from Coe $(2013,11)$.

producer-driven GVCs (high-tech sectors), manufacturers are placed upstream; they control R\&D and the design of products as well as most of the assembly, fragmented in different countries. On the other hand, in buyer-driven GVCs, retailers control the production by focusing on marketing and sales, and suppliers provide finished goods.

Upgrading is conditioned by factors internal and external to the firm. How to upgrade the position by moving into higher valueadded activities in a global value chain is a challenge for countries and companies. GVcs are expected to bring gains to the countries in terms of improved competitiveness, better access to global markets, and expansion of production and jobs in these countries, but this is not automatic. Policymakers need to know what contributes to production at each stage of the supply chain and how to upgrade the position in the GVcs in order to improve growth and development. According to the literature, public support has a stronger impact on buyer-driven than producer-driven chains (Humphrey and Schmitz 2001).

A wide literature has developed over the last decade on the successful upgrading 3 of enterprises (Kaplinsky and Farooki 2010; UNIDO 2004; OECD 2013) that distinguishes between several types of upgrading:

- process upgrading (more efficient operations performance),

- product upgrading (higher quality goods or introducing new products faster than competitors),

- functional upgrading (assuming functions of the chain with greater value-added design, marketing, R\&D, etc.),

- inter-sectoral or chain upgrading (new production activities, moving from one chain to another). 
The value generation of a firm participating in GVCs is strongly related to the non-replicability of their products and services (OECD 2013). This refers to those elements of the value chain that cannot be rapidly provided by other firms i.e., knowledge-based capital (квс) that includes computerised information (software, databases), innovative property (patents, designs, trademarks), and economic competencies (know-how, brand, etc.). Lately, management skills are also shown to be increasingly important factors in the quality of goods that are produced and the use of imported inputs as well as export performance (Bloom et al. 2013).

The increasingly complex trading environment requires a greater focus on domestic whole-of-the-government approaches. This calls for the complete and coherent design of related policies to move towards higher value-added activities in the Gvcs and to best derive benefits from GVc participation. The literature proposes that governments (OECD 2007; 2008; Cusolito, Safadi, and Taglioni 2016), the business community, and international organizations facilitate SME participation in Gvcs through policies, practices, and targeted support programmes, including:

- policies for improving business environment (well-designed structural policies, competition, international trade and investment, financial markets, labour market, education, and internationalization policies),

- target support programmes (access to finance, information, consultation, etc.),

- collective action and co-operation (supporting industry groupings, promoting clusters and networks - especially where there is a potential in knowledge-intensive and export-oriented market segments and for supporting R\&D for continuous innovation),

- promoting the capacity for innovation by local SMEs (supporting skills development, upgrading products and processes, internationalisation, Іст implementation),

- enhancing SME value obtained from intellectual assets and intellectual property (providing guidance and financial and legal instruments to adopt IP rights developed in universities and research centres, facilitating filing the patents by SMEs),

- facilitating the adoption of product quality and process standards (providing information).

Creating a business-friendly environment that will attract investment, nurture efficiency, and build competitiveness is important 
(horizontal measure). However, this may not be enough. Government policies and programmes also play an influential role in integration into particular sectors by designing incentives for the sectors where resources offer a comparative advantage (entrepreneurship and innovation programmes in order to build up capacities in different sectors). Low and Tijaja (2013) suggest broadbased policies relating to trade facilitation, connectivity, human capital, and innovation. As these policies may work less effectively or too slowly, sector-specific interventions (certain activities along the value chain) could be introduced. Different strategies include import substitution, export-led growth, domestic resource-based industrialization and, to some degree, industrialization through innovation.

In a nutshell, in order to best derive benefits from GVc participation, coordinated actions of all stakeholders are required (governments, businesses, and international organizations) in order to support public and private investments (investment policies, trade, business environment, skills upgrading). The ability to benefit from GVCs is linked to innovation and knowledge-based assets, such as R\&D, branding, design, and software, to enable companies to differentiate their products and economies to strengthen their presence in GVCS.

\section{Analysis of the Integration of Selected Economies into Gves} This section firstly explains the indicators for measuring participation in GVcs, followed by evaluation (analysis) of selected countries' participation in global value chains in the period from 1995 to 2011.

A comparative advantage in the new trade models requires them to be based on activities and tasks (Gereffi 1999), as trade measured in gross terms has been unable to reflect modern trade patterns, characterized by increased international production fragmentation (Jara and Escaith 2012).

Therefore, when analysing data and indicators of the selected economies, we apply a GVC approach, based on a decomposition of value added into the domestic and foreign components in order to better assess the challenges and the opportunities of higher production fragmentation.

Our goal is to find the trends and the differences between large and small countries and what are the factors to upgrade their position in the Gvcs.

Analysis is based on the OECD - wто Tiva database, jointly launched by the Organisation for Economic Co-operation and Development (OECD) and the World Trade Organisation (wто) in 2013, and the 
World Input-Output Database (wIOD), a joint product of 11 European research institutions, ${ }^{4}$ as well as data published in the $\mathrm{EU}$ Industrial Structure Report 2013 and wто International Trade Statistic Report 2015. For Slovenia, data is also gathered from the survey for Smart Specialisation Strategy (Burger and Kotnik 2014).

INDICATORS FOR MEASURING PARTICIPATION IN GVCS

The indicator for global value chain participation (the Gvc participation index), proposed by Koopman et al. (2010), 5 indicates the extent to which a country is involved in a vertically fragmented production process in relative and absolute terms. It distinguishes the use of:

- foreign inputs in exports (backward participation - vs),

- the use of domestic intermediates in third country exports (forward participation - vs1),

- the index of the number of production stages which shows how long global value chains are and highlights the domestic and international parts of the Gvc.

The indicator distance to final demand (Backer and Miroudot 2013) points out the upstreamness of countries and their position in the value chain. Countries upstream produce raw materials or intangibles at the beginning of the production process (e.g. research, design), while countries downstream do the assembly of processed parts or specialise in customer services.

By combining vs and vs1 shares, we can have a comprehensive assessment of a country's participation in Gvcs, both as a user of foreign inputs (upstream links, i.e. backward participation) and a supplier of intermediate goods and services used in other countries' exports (downstream links, i.e. forward participation). An important aspect to look at is the extent to which countries are specialised in particular activities. The standard tool to analyse this is the revealed comparative advantage ( $\mathrm{RCA}$ ) index, which compares a country's share in world exports by product group or industry to its share in total exports. ${ }^{6}$ In a case study of Slovenia, we use the ratio calculated based on GVC income.

To sum up, Gvc participation (vs and vs1) indicates the share of a country's exports that is part of a multi-stage trade process. It is the foreign value added used in a country's exports (upstream perspective) plus the value added supplied to other countries' exports (downstream perspective), divided by total exports (Coe 2013; Hummels, Ishii, and Yi 2001). 
TABLE 2 Gross Exports, Exports of Final Products, Domestic Value-Added Exports and Foreign Value-Added Exports 1995-2011

\begin{tabular}{|c|c|c|c|c|c|c|c|}
\hline \multirow[t]{3}{*}{ Country } & \multicolumn{3}{|c|}{ Exports (Ex) } & \multicolumn{4}{|c|}{ Exports final products (EXFP) } \\
\hline & 1995 & 2011 & Index & 1995 & $\%$ & 2011 & $\%$ \\
\hline & a & $\mathrm{b}$ & $\mathrm{b} / \mathrm{a}$ & C & $\mathrm{c} / \mathrm{a}$ & $\mathrm{d}$ & $\mathrm{d} / \mathrm{b}$ \\
\hline $\mathrm{CA}$ & 204244 & 523357 & 256 & 75432 & 36.9 & 156032 & 29.8 \\
\hline US & 770710 & 1908453 & 247 & 342245 & 44.4 & 742362 & 38.8 \\
\hline JP & 428833 & 893342 & 185 & 196853 & 40.7 & 296617 & 33.2 \\
\hline $\mathrm{DE}$ & 543064 & 1431864 & 263 & 230150 & 42.3 & 531486 & 37.1 \\
\hline FR & 338448 & 709536 & 209 & 152213 & $44 \cdot 9$ & 304699 & 42.9 \\
\hline PL & 30933 & 213576 & 690 & 13188 & 42.6 & 85746 & 40.1 \\
\hline ES & 132774 & 445479 & 335 & 69583 & 52.4 & 198752 & 44.6 \\
\hline UK & 314934 & 738630 & 234 & 129401 & 41.0 & 261908 & 35.4 \\
\hline AT & 78127 & 181446 & 232 & 35843 & 45.8 & 71630 & 39.4 \\
\hline $\mathrm{BE}$ & 131045 & 241230 & 184 & 52746 & 40.2 & 81529 & 33.7 \\
\hline $\mathrm{CZ}$ & 27484 & 153595 & $55^{8}$ & 11255 & 40.9 & 61293 & 39.9 \\
\hline IR & 47504 & 224543 & 472 & 20926 & 44.0 & 86964 & 38.7 \\
\hline SK & 10022 & 70231 & 700 & 3968 & 39.5 & 26306 & 37.4 \\
\hline SI & 10290 & 28423 & 276 & 4843 & 47.0 & 10896 & 38.3 \\
\hline $\mathrm{CN}$ & 143426 & 1969214 & 1372 & 70619 & 49.2 & 868112 & 44.0 \\
\hline
\end{tabular}

EVALUATION OF SELECTED COUNTRIES' PARTICIPATION

IN GLOBAL VALUE CHAINS IN THE PERIOD FROM 1995 TO 2011

In this section, we analyse the participation of the $\mathrm{EU}$ in GVCS in the period from 1995 to 2011 (the latest available data in the овCD-wто Tiva database) and within the $\mathrm{Eu}$ integration, five large (Germany, France, United Kingdom, Spain and Poland) and six small countries (Austria, Belgium, Ireland, Czech Republic, Slovakia and Slovenia) as well as four major EU partners (USA, Canada, China and Japan). Our aim is to identify common trends and differences of integration in GVCS.

Gross exports, exports of final products, and domestic value-added exports and foreign value added-exports in 1995 and 2011 are shown in table 2.

In all analysed economies, gross exports (Ex) substantially increased in the period from 1995 to 2011 as well as the domestic value added in gross exports (DVA/Ex), with the largest increase of both indicators in China, Slovakia, Poland, Czech Republic, and Ireland. However, in general the increase of the $\mathrm{DVA} / \mathrm{Ex}$ ratio was lower than gross exports. The data also suggests the quite generalised growing 
TABLE 2 Continued from the previous page

\begin{tabular}{|c|c|c|c|c|c|c|}
\hline \multirow[t]{3}{*}{ Country } & \multicolumn{3}{|c|}{ Exports (Ex) } & \multicolumn{3}{|c|}{ Exports final products (EXFP) } \\
\hline & 1995 & 2011 & Index & 1995 & 2011 & Index \\
\hline & $\mathrm{e}$ & $\mathrm{f}$ & $\mathrm{f} / \mathrm{e}$ & $\mathrm{g}$ & $\mathrm{h}$ & $\mathrm{h} / \mathrm{g}$ \\
\hline $\mathrm{CA}$ & 153460 & 298610 & 195 & 49469 & 122233 & 247 \\
\hline US & 679392 & 1611061 & 237 & 87965 & 284955 & 324 \\
\hline JP & 453335 & 757991 & 167 & 26950 & 130431 & 484 \\
\hline $\mathrm{DE}$ & 460138 & 1060071 & 230 & 80410 & 363647 & $45^{2}$ \\
\hline FR & 278167 & 527612 & 190 & 58244 & 177097 & 304 \\
\hline PL & 25793 & 142929 & 554 & 4952 & 68494 & 1383 \\
\hline ES & 106916 & 323392 & 302 & 25341 & 118890 & 469 \\
\hline UK & 255884 & 563148 & 220 & 57129 & 168667 & 295 \\
\hline AT & 60881 & 129268 & 213 & 16614 & 49835 & 300 \\
\hline $\mathrm{BE}$ & 89816 & 155915 & 174 & 40384 & 82265 & 204 \\
\hline $\mathrm{cz}$ & 18930 & 83390 & 441 & 45965 & 69011 & 150 \\
\hline IR & 29010 & 124134 & 428 & 18151 & 96039 & 529 \\
\hline SK & 6763 & 37182 & 549.7 & 3172 & 32759 & 1033 \\
\hline sv & 6963 & 18058 & 259 & 3322 & 10235 & 308 \\
\hline $\mathrm{CN}$ & 95394 & 1330580 & 1395 & 47802 & 630828 & 1320 \\
\hline
\end{tabular}

Notes Calculations based on oECD-wto (2016). Estimates for certain tiva indicators are now available for 2012-2014, however they are based on older data and therefore not included in the table.

importance of the acquisition of value added from foreign providers during the period, with the highest increase in Poland, China, and Slovakia, followed by Japan, Germany, and Spain. Further analysis of domestic value added in gross exports shows that the difference is smallest in the USA and Japan (15\%), between $23 \%$ and $30 \%$ in larger $\mathrm{EU}$ countries, and higher in smaller countries (Austria being an exception). In all analysed countries, a share of final products in gross exports decreased, which is consistent with the theoretical background (Banga 2013,4) on growing inter-linkages in trade where trade in intermediate products is growing faster than trade in finished products.

In order to estimate to what extent selected countries are involved in vertically fragmented production and exploit comparative advantages, we now look at the Gvc participation indexes. These indexes show the extent to which exporters depend on foreign suppliers for intermediate inputs $(\mathrm{FVA} / \mathrm{EX})$ and share of DVA in foreign exports to third countries.

Table 3 reveals that in all countries the GVc index increased in the period from 1995 to 2011, despite a slight decrease of the backward 
TABLE 3 GVc Participation Indexes for Selected Countries

\begin{tabular}{|c|c|c|c|c|c|c|c|c|c|c|}
\hline \multirow[t]{2}{*}{ Country } & \multicolumn{2}{|c|}{$\begin{array}{l}\text { Participation } \\
\text { index, } \\
\text { backward }\end{array}$} & \multicolumn{2}{|c|}{$\begin{array}{l}\text { Participation } \\
\text { index, } \\
\text { forward }\end{array}$} & \multicolumn{2}{|c|}{$\begin{array}{l}\text { GVC } \\
\text { Participation } \\
\text { index }\end{array}$} & \multicolumn{2}{|c|}{$\begin{array}{l}\text { Distance } \\
\text { to final } \\
\text { demand }\end{array}$} & \multicolumn{2}{|c|}{$\begin{array}{l}\text { Number of } \\
\text { production } \\
\text { stages }\end{array}$} \\
\hline & 1995 & 2011 & 1995 & 2011 & 1995 & 2011 & 1995 & 2011 & 1995 & 2011 \\
\hline $\mathrm{CA}$ & 23.5 & 19.5 & 9.6 & 15.2 & 33.2 & 34.8 & 1.8 & 1.8 & 1.7 & 1.7 \\
\hline US & 8.4 & 11.3 & 24.5 & 28.5 & 32.9 & 39.8 & 1.7 & 1.6 & 1.7 & 1.6 \\
\hline JP & 6.8 & 14.8 & 22.4 & 33.0 & 29.3 & $47 \cdot 7$ & 1.8 & 1.8 & 1.7 & 1.8 \\
\hline EU 27 & 9.0 & 12.5 & 15.2 & 17.8 & 24.1 & 30.2 & 1.8 & 1.9 & 1.8 & 1.8 \\
\hline $\mathrm{DE}$ & 18.7 & 26.8 & 22.6 & 22.8 & 41.3 & 49.5 & 1.7 & 1.9 & 1.7 & 1.8 \\
\hline FR & 17.8 & 24.7 & 21.9 & 21.1 & 39.8 & 43.0 & 1.7 & 1.7 & 1.6 & 1.7 \\
\hline $\mathrm{PL}$ & 15.4 & 27.9 & 17.5 & 20.5 & 32.9 & 48.3 & 1.9 & 1.9 & 2.0 & 1.9 \\
\hline ES & 20.6 & 20.7 & 17.7 & 21.1 & 40.3 & 41.9 & 1.8 & 1.9 & 2.1 & 1.9 \\
\hline UK & 20.7 & 17.3 & 21.8 & 25.1 & 42.5 & 42.4 & 1.9 & 1.9 & 1.8 & 1.8 \\
\hline $\mathrm{AT}$ & 27.5 & 31.6 & 20.9 & 24.2 & 48.4 & 55.8 & 1.7 & 2.0 & 1.6 & 1.9 \\
\hline $\mathrm{BE}$ & 39.0 & 35.0 & 18.3 & 22.6 & $57 \cdot 3$ & 57.6 & 1.9 & 2.0 & 1.9 & 1.9 \\
\hline$c z$ & 32.1 & 39.4 & 19.4 & 23.0 & 51.5 & 62.4 & 2.1 & 2.2 & 2.1 & 2.2 \\
\hline IR & 38.4 & 42.3 & 13.0 & 18.8 & 51.4 & 61.1 & 1.9 & 2.1 & 1.9 & 1.9 \\
\hline SK & 35.6 & $44 \cdot 3$ & 20.7 & 17.9 & 56.4 & 62.2 & 2.2 & 2.0 & 2.1 & 2.1 \\
\hline sv & 30.7 & 34.4 & 14.7 & 18.2 & $45 \cdot 4$ & 52.6 & 2.0 & 1.9 & 2.1 & 1.9 \\
\hline $\mathrm{CN}$ & 11.9 & 18.8 & 13.9 & 13.4 & 25.7 & 46.1 & 2.3 & 2.7 & 2.3 & 2.5 \\
\hline
\end{tabular}

Notes Based on data from the oECD-wto (2016).

participation index in Canada and forward participation in France showing stronger engagement in international production linkages. The highest increase of the GVC index was recorded in China (20\%), Japan (18\%), Poland (13\%), and Czech Republic (11\%), followed by Austria, Germany, USA, and Slovenia (7\%). Index distance to final demand (Fally 2012) that measures how many stages of production are left before goods and services reach final consumers increased or remained at the same level. An increase in upstreamness shows the economies are now more specialised in the production of the inputs at the beginning of a value chain. The increase of indicators is high in China, followed by Austria, and we can see positive trends in Czech Republic, Belgium, Spain and Germany. Only usA and Slovenia recorded a decrease due to specialisation in goods and services more downstream (OECD 2013, 19).

Analysis of the GVC participation index of selected economies shows stronger forward linkages (DVA that enters other countries' exports) for Japan, United Kingdom, and USA and EU integration. Other analysed larger and smaller $\mathrm{E} u$ countries have stronger backward linkages i.e., they source more intermediate goods from abroad 
and therefore their vertical specialisation is higher than in larger or more resource-rich countries. There is a positive relationship between the domestic value-added content of exports and economic size. Small and open economies source more inputs from abroad and the GVC participation index (over 50\%) is higher for Austria, Belgium, Czech Republic, Ireland, Slovakia and Slovenia. Statistical data analysis confirms the argument on the participation index to be correlated with the size of a country.

\section{A Case Study: Slovenia's Gvc Integration and Policies for Supporting Upgrading}

After analysing the literature on GVc integration and upgrading and evaluating the selected countries' participation in global value chains in the period from 1995 to 2011, we apply a case study analysis of Slovenia, a small, open economy highly dependent on international trade.

\section{SLOVENIA'S GVC INTEGRATION}

This section utilizes the analysis of statistical data on GVC integration (овCD-Wто TIVA database and relevant studies) and government policies/institutions/instruments in place to support SME integration and upgrading into GVCs, based on information published on web pages of key government actors and the applied participant observation method.

A country's integration into Gvcs (previous chapter) shows Slovenia has been rapidly integrating into world markets from 1995 when the GVC index was $45.4 \%$ (backward participation $30.7 \%$ and forward participation 14.7\%) (OECD 2012; 2013). By 2011, the index grew to $52.6 \%$ and was, like in other analysed small economies (Austria, Belgium, Czech Republic, Ireland, Slovakia), amongst the highest, mainly driven by the use of foreign intermediates in exports (backward participation of $34.4 \%$ and forward participation of $18.2 \%$ ). Among manufacturing industries; chemicals, basic materials, machinery, electrical, and transport equipment are those that source large amounts of intermediates from abroad and include them in their exports (European Commission 2013; OECD 2017a). Almost half of the final demand for manufactured goods and market services in Slovenia represents value added that has been created abroad. This is in line with the argument on smaller countries showing on average lower shares of domestic value added in final demand reflecting the fewer sourcing opportunities within their domestic economy. More than $30 \%$ of the value of Slovenia's manufacturing exports represents 
services value added, especially business and distribution services (OECD-WTO 2015).

Sector specialization and revealed comparative analyses (RCA) for Slovenia in the period from 2000 to 2012 conducted by the European Commission $(2013,25-26,76)$, shows increased sector specialization and RCA in: chemicals and chemical products, pharmaceuticals, rubber and plastic and other non-metallic mineral products, basic metals and metal products, electrical equipment, and motor vehicles, as well as other transport equipment and services transport and storage. Similar findings are in the study analysing RCA separately for intermediate and final products (in the period 20082012) by Burger and Kotnik (2014), where the productivity growth and RCA were shown in the manufacturing of electric motors, generators, transformers, and electricity distribution and control apparatus; manufacturing of medical and dental instruments and supplies, preparation, and spinning of textile fibres; manufacturing of products of wood; articles of cork, straw, and painting material; manufacturing of paints, varnishes, and similar coatings, painting ink and mastics and manufacturing of parts and accessories for motor vehicles. RCA advantages in both intermediate and final products were recorded in wood and products of wood and cork, pulp and paper products; rubber and plastic products; other non-metallic mineral products; basic materials and fabricated metal products; machinery and equipment; electrical machinery and apparatus; motor vehicles; where chemicals are only in end products.

In sum, data of revealed comparative advantages (RCA) and technological specialization show that a stable set of key economic activities (pharma, materials, machinery and equipment, auto, electrical and rubber and plastics) exists in Slovenia, representing a quarter of Slovenia's value added (SVRK 2015, 10). The integration is lower in companies from low-tech industry, with the exception of mostly foreign market-oriented leather and textile industries (European Commission 2013). Therefore, incorporating more domestic content in exports and moving up the value chain remains a challenge. With the majority of Slovenian companies belonging to the category of small enterprises, the challenging issue for policymakers is how to raise GVC integration among this segment.

INSTITUTIONS, POLICIES AND INSTRUMENTS SUPPORTING GVC UPGRADING

In order to make proposals for further improvements to policies supporting upgrading the position of small and medium enterprises into 


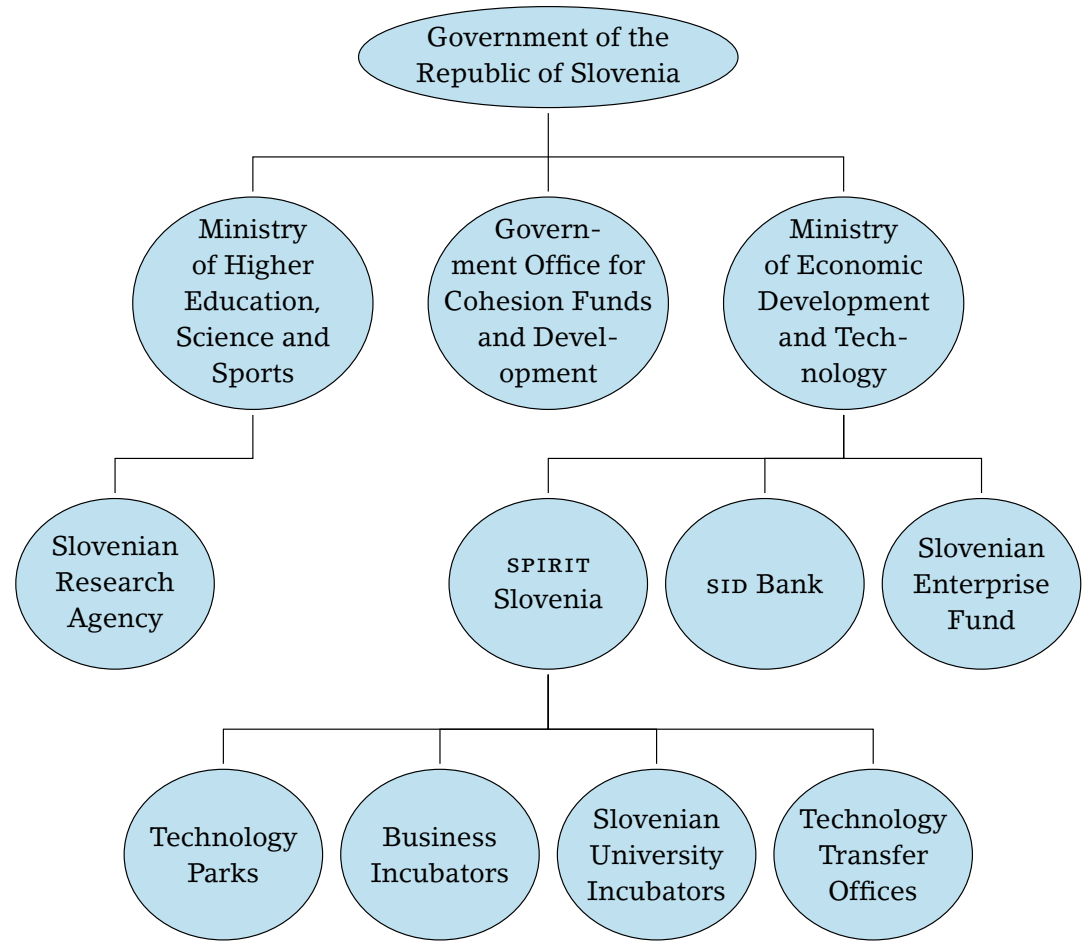

FIGURE 1 Institutional Structure for Supporting GvC Upgrading

GVCS, we analyse institutional structure (based on information published on the web pages, applied participant observation method), and implemented and planned policies/instruments aiming to enhance further integration and upgrading into Gvcs.

Slovenia has a rather complex scheme of institutions supporting SMES and innovation. In addition to the two ministries and a government office involved in the entrepreneurship and innovation policies i.e., Ministry of Higher Education, Science and Sports (MHess), Ministry of Economic Development and Technology (MEDT), and Government Office for Cohesion Funds and Development (GOCFD), there are several agencies and other intermediaries established for providing funding for the activities of innovation-supportive institutions and Smes: Slovenian Research Agency (SRA), Public Agency for Entrepreneurship, Internationalization, Foreign Investments and Technology (SPIRIT Slovenia), Slovenian Enterprise Fund (SEF), and Slovenian Development and Export Bank (sID Bank Inc.)

Published documents and surveys (OECD 2012; 2013; Bučar, Jak- 
lič, and Udovič 2010) show there are several policies for improving business environment, promoting the capacity for innovation, and targeting support programmes for SMEs already implemented in Slovenia. Several instruments were implemented for technology funding, addressing issues like innovation system (intra-firm, cooperation of different actors, skills, etc.). SPIRIT Slovenia employs a wide range of financial and soft i.e., consulting, support schemes that are directed either to SMES or to intermediaries (technology parks, business and university incubators, technology transfer offices, one stop shop - VEM points, European Enterprise Network, etc.). Funding instruments for supporting RDI of SMES run by the agency in the period from 2007 to 2013 were voucher system for consultancy and training, innovation voucher, young researchers, cofinancing of employment of researchers in enterprises, co-financing of one-stop shop services - mainly funded by the Cohesion funds (see http://www.spiritslovenia.si). SEF specialises in financing for small and medium-size enterprises during the whole life cycle and offers the following instruments: grants for start-ups, seed capital, venture capital, technology equipment subsidies, guarantees for bank loans with subsidised interest rate, and guarantees for bank loans for technological innovation projects and microloans. The instruments for start-ups are associated with non-financial support (training, mentoring, promotional activities. ${ }^{7}$ sid Bank Inc. mainly acts as a public export and development bank (export insurance, co-financing) and lately offers direct financing to support SMES in financing RDI investments. In 2013, a Loan Fund for SME financing amounting to 500 mio EUR was established by MEDT and SID Bank to provide microfinancing, financing of investments, and employment and investments into RDI to the SMES (http://www.sid.si). Some major instruments promoting innovation and business investment in research and development are also provided directly by the two ministries. In order to foster science-industry co-operation, MHEss financed 7 Competence Centres (45 mio EUR) and 8 Centres of Excellence (77 mio EUR) (http://www.mizs.gov.si). MEDT financed 17 Development Centres (179 mio EUR) and provided grants for technological investments and strengthening of $\mathrm{R} \& \mathrm{D}$ departments in enterprises, and international development projects in the context of the initiatives Eurostars and Eureka (http://www.mg.gov.si).

Analyses (Bučar, Jaklič, and Udovič 2010; OECD 2012; OECD 2014a; Burger and Kotnik 2014; SVRK 2015, 6) reveal strengths as well as some weaknesses of the Slovenian Innovation System. In spite of strong involvement of Slovenian stakeholders in international Gvcs 
and intensive research, development and innovation policy in the last 16 years, and a stimulating tax environment for RDI $(100 \%$ tax deduction for R\&D and $40 \%$ for investments) as well as an educated labour force and extensive investments, innovation is still insufficient - although expenditures on $\mathrm{R} \& \mathrm{D}$ have been increasing since the transition and institutions engaged in science, technology, and innovation are well-developed. Slovenia's potential for benefitting from technology spillovers through inward FDI is not fully realised due to small inflows of FDI compared to other countries (OECD 2012). There are also barriers to entrepreneurship, such as insufficient access to finance (OECD 2014a). The Slovenian innovation system also appears unable to maximise benefits of existing technologies for new innovative purposes, given the low level of patents and trademarks per capita and the small share of high technology exports. In addition, analyses show lack of co-ordination between government institutions, weak co-operation between knowledge institutions and companies, insufficient and complicated instruments, absence of systemic incentives within knowledge institutions, fragmentation of support institutions and instruments, implementation deficit, a discrepancy between good strategic papers and implementation, and several of the main exporting sectors investing insufficiently in R\&D. We can also conclude there are apparently overlapping responsibilities (e.g. SEF and SID Bank, SPIRIT, and intermediaries).

The strategic documents recently adopted by the Government: Research and Innovation Strategy of Slovenia 2011-2020 (RISS), $\mathrm{Na-}$ tional Higher Education Programme 2011-2020 (NHEP), Slovenian Industrial Policy 2013-2020 (SIP), Smart Specialisation Strategy (s4), Operational Programme 2014-2020 (оP) and Digital Slovenia 2020 (Ds) put emphasis on measures supporting entrepreneurship and a business-friendly environment, innovation, skills, and internationalization, and therefore respond to the challenge to increase the share of enterprises integrated in global value chains. However, Slovenia's development strategy for the same period is still in a preparation phase.

Like in other EU member states, the Smart Specialisation Strategy $(\mathrm{s} 4)^{8}$ is a key strategic document of the Government of the Republic of Slovenia in the field of innovation. The Strategy addresses a broad range of development policies related to innovation, in particular RISS and SIP. The Strategy also addresses some parts of the education system, international relations and regulatory environment, as well as the funding programmes and stakeholders. The aim is an 
integrated strategic approach in providing a consistent policy mix for financial support to the identified priority areas, based on a clearly stated three-level governance system (Governmental level, National Innovation Platform and Strategic Partnerships) and the main objectives in the field of RDI: to increase the share of innovation active enterprises to $55 \%$ in 2023 and in the field of SMES, to promote the creation and operation of businesses, especially start-ups and to increase the value added by SMEs. The documents clearly state the goal to increase the share of enterprises integrated in global value chains as well as to increase high-tech exports among total exports.

The planned measures put emphasis on networking and strengthening the links and synergies in the innovation system by targeting development of international consortia and partnerships, encouraging innovation processes and associated investment (development of new products, services, processes, investments in non-technological innovation i.e., new business models, eco-innovation, pilot lines and strengthening of development units in enterprises with multi-and interdisciplinary knowledge [creativity, design-management, etc.]), internationalisation and гст implementation. In order to enhance SMES' value obtained from intellectual assets and intellectual property, the Government also plans to provide guidance, financial and legal instruments to adopt IP rights developed in universities and research centres, and facilitation of the filing of patents by SMES.

The s4 has a goal to strengthen the competitiveness of the economy by enhancing its innovation capacity and international dimension, including FDI, a key element of the policy mix, addressing efficient investments in RDI, upgrading competences and skills, entrepreneurship, and innovation, as well as innovative procurement. Special emphasis will also be given to encouraging participation in EU programmes, especially Horizon 2020 and cosme.

We can conclude the Government plans to implement some instruments based on proposals of European Commission (2011) and OECD $(2012 ; 2014 \mathrm{~b})$ to further strengthen the innovation system, to foster productivity gains in all sectors, to attract FDI, and to diversify into economic activities in higher value added in order to maximise the benefits of GVCs. To boost innovation, the government plans to continue supporting technological and non-technological innovation, the enhancement of knowledge-intensive skills (engineering, design, marketing, information technology) and R\&D and associated investments including advanced machinery, software, databases, branding, firm-specific human capital, and organisational capital.

In sum, analysis shows the policies with clear goals and the instru- 
ments to support the integration of SMEs into Gvcs in Slovenia exist, but we found the institutional network is fragmented, and due to a lack of co-ordination in some cases, instruments are overlapping. Moreover, more importantly, implementation remains a challenge. This could be improved by (a) institutional structure with clearly divided responsibilities, and (b) implementation of a monitoring and evaluation system on a horizontal level. Efficient co-ordination of all actors will have to be implemented when supporting SME integration and upgrading in Gves.

\section{Conclusions and Recommendations}

With the growth of GVCs, economies are increasingly specialised in specific activities (process and value being added in the multiple countries that are part of the chain). Integration of small and medium enterprises into global value chains is an important determinant of the export performance and competitiveness.

This paper evaluates the countries' participation in Gvcs in the period from 1995 to 2011 and presents key challenges policymakers have to take into account when adjusting policy measures for increasing SME integration in GVCS in order to improve growth and development.

A key finding is that a 'whole of the chain' approach is needed with coordinated actions of all stakeholders - governments, businesses, international organisations, and that governments should implement policies and targeted support programmes, enabling companies to differentiate their products, linked to innovation, and knowledge-based assets, etc. in order to best respond to the reality of more interconnected economies and to draw the greatest benefits from engagement in Gvcs.

For Slovenia, this study shows the country has been rapidly integrating into GVCs and has well-designed policies and a relatively extensive support network, but we propose some actions for further improvements. As the institutional network is fragmented, and due to a lack of co-ordination in some cases where instruments are overlapping, we suggest improving the institutional structure by clearly dividing responsibilities among institutions and to implement a monitoring and evaluation system on a horizontal level. We also point out the importance of continuity and keeping policy uncertainty to a minimum. Since the majority of Slovenian companies are SMES, we propose targeted support programmes for SMES by putting more emphasis on awareness raising on the potential of participation in GVcs, supporting technological and non-technological inno- 
vation, enhancing knowledge-intensive skills and associated investments, attracting FDI, and promoting the development of industrial clusters, etc.

We suggest further analysis of value added creation on companies (size), on an industry-specific level, and geographic distribution. This would help policymakers adjust even more targeted measures to derive the greatest benefits from Gvc participation. Therefore, in our opinion, investment in a scaling-up of microdata and existing data collections is needed. Currently, the availability of data on international trade by company size is limited (incomplete, inconsistent country coverage, differences in reporting standards across countries). OECD-Wто тіVA indicators should be extended to years that are more recent as well.

\section{Acknowledgements}

I am grateful to Alejandro Jara, International Tade Lawyer (Former Deputy Director General, World Trade Organisation) for giving invaluable inputs to the content of the article.

\section{Notes}

1 OECD-wTo Tiva database shows that indirect contribution of SMES is several times greater than the direct participation in all countries for which data is available (see https://stats.oecd.org).

2 Estimates for certain riva indicators are now available for 2012-2014, however they are based on older data and therefore not included in our research.

3 Upgrading means innovating better or faster than competitors.

4 World Input-Output Database available at www.wiod.org and described by Timmer (2012).

5 A country is well-integrated into GVc if it sources many inputs from abroad and a large proportion of its own value added is part of third countries' exports relative to its total exports.

6 EU Industrial Structure Report (European Commission 2013, 25-27) shows sector specialisation indices of the $\mathrm{EU}$ member states for the period 2000-2012.

7 More data can be found at http://www.podjetniskisklad.si. In the period 2004-2013 the Fund approved 4.307 projects with 673 mio EUR and enhanced 1.24 bn EUR of SMEs investments.

8 Smart Specialization is a strategic approach to economic development through targeted support for research and innovation. It involves a process of developing a vision, identifying the place-based areas of greatest strategic potential, developing multi-stakeholder governance mechanisms, setting strategic priorities, and using smart policies to maximize the knowledge-based development potential of a region, regardless of 
whether it is strong or weak, high-tech or low-tech. In line with the European Commission's overall growth strategy, Eu2020, the Commission launched the Strategies for Smart Specialisation Platform (s3 Platform) in June 2011 to provide professional advice to $\mathrm{EU}$ member states and regions for the design of their Research and Innovation strategies for smart specialisation.

\section{References}

Antras, P., and D. Chor. 2013. 'Organizing the Global Value Chain.' Econometrica 81 (6): 2127-204.

Backer, K. D., and S. Miroudot. 2013. 'Mapping Global Value Chains.' OECD Trade Policy Papers 159, OECD, Paris.

Baldwin, R. E., and A. Venables. 2013. 'Spiders and Snakes: Offshoring and Agglomeration in the global Economy.' Journal of International Economics 92 (1): 51-62.

Banga, R. 2013. 'Measuring Value in Global Value Chains.' http://unctad .org/en/PublicationsLibrary/ecidc2013misc1_bp8.pdf

Bloom, N., E. Benn, M. Aprajit, M. David, and J. Roberts. 2013. 'Does Management Matter? Evidence from India.' The Quarterly Journal of Economics 128 (1): 1-51.

Bučar, M., A. Jaklič and B. Udovič. 2010. National System of Innovation in Slovenia. Centre of International Relations cIR Analyses 4. Ljubljana: Fakulteta za družbene vede.

Burger, A., and P. Kotnik. 2014. 'Professional Analysis as the Basis for the Smart Specialization Strategy.' Faculty of Economics, Ljubljana.

Coe, N. M. 2013. 'Global Value Chains/Global Production Networks: Organizing the Global Economy.' Presentation to the MIER's National Economic Outlook Conference 2014-2015, Kuala Lumpur, 26 November.

Costinot, A., J. Vogel, and S. Wang. 2013. 'An Elementary Theory of Global Supply Chains.' Review of Economics Studies 80 (1): 109-44.

Cusolito, A. P., R. Safadi, and D. Taglioni. 2016. Inclusive Global Value Chains: Policy Options for Small and Medium Enterprises and LowIncome Countries. Washington, DC: World Bank.

Elms, D. K., and P. Low. 2013. Global Value Chains in a Changing World. Geneva: wто.

European Commission. 2011. Innovation Union Competitiveness Report. Luxembourg: Publications Office of the European Union.

- 2015. Annual Report on European Smes 2014/2015. Brussels: European Commission.

2013. Competing in Global Value Chains: Eu Industrial Structure Report. Brussels: European Commission.

Fally, T. 2012. 'Production Staging: Measurements and Facts.' https:// www2.gwu.edu/ iiep/assets/docs/fally_productionstaging.pdf 
Feenstra, R. C. 1998. 'Integration of Trade and Disintegration of Production in the Global Economy.' Journal of Economic Perspectives 12 (4): 31-50.

Gereffi, G. 1999. 'International Trade and Industrial Upgrading in the Apparel Commodity Chain.' Journal of International Economics 48 (1): 37-70.

Hummels, D., J. Ishii, and K.-M. Yi. 2001. 'The Nature of Growth of Vertical Specialization in World Trade.' Journal of International Economics 54 (1): 75-96.

Humphrey, J., and H. Schmitz. 2001. 'Governance in Global Value Chains.' IDs Bulletin 32.3.

Jara, A., and H. Escaith. 2012. 'Global Value Chains, International Statistics and Policymaking in a Flattening World.' World Economics 13-4 (October-December): 5-18.

Kaplinsky, R., and M. Farooki. 2010. 'What Are the Implications for Global Value Chains when the Market Shifts from North to South?' In Global Value Chains in a Postcrisis World, edited by O. Cattaneo, G. Gereffi, and C. Staritz, 2-5. Washington, Dc: The World Bank.

Koopman, R., W. Powers, Z. Wang, and S.-J. Wei 2010. 'Give Credit Where Credit is Due: Tracing Value Added in Global Production Chains.' NBER Working Paper 16426, National Bureau of Economic Research, Cambridge, MA.

Low, P., and J. Tijaja. 2013. 'Sharing in Global Value Chains: The Role of Industrial Policy.' Asian Perspectives Global Issues: Real Sector Issue Brief, no. 2.

OECD. 2007. 'Enhancing the Role of Smes in Global Value Chains.' https://www.oecd.org/cfe/smes/38774814.pdf

- 2008. Enhancing the Role of SMEs in Global Value Chains. Paris: OECD.

- 2012. ofcd Reviews of Innovation Policy: Slovenia. Paris: oecd.

_. 2013. 'Global Value Chains, Development and Competitiveness.' Discussion Paper presented at the of CD meeting, Paris, 19 March.

- 2014a. Slovenia: Reforms for a Strong and Sustainable Recovery. Paris: OECD.

- 2014b. 'Global Value Chains: Challenges, Opportunities, and Implications for Policy.' Report prepared for G 20 Trade Ministers Meeting, Sydney, 19 July.

_. 2017a. 'Slovenia: Trade and Investment Statistical Note.' http:// www.oecd.org/investment/SLOVENIA-trade-investment-statistical -country-note.pdf

- 2017b. 'овсD Ministerial Conference on Smes: Revised Background Notes to the Three Plenary Sessions.' Paris, 25 October.

ofcD-w to. 2015. 'Trade in Value Added: Slovenia.' https://www.oecd .org/sti/ind/tiva/CN_2015_Slovenia.pdf 
2016. 'Trade in Value Added (Tiva) Database: December 2016.' http://stats.oecd.org/Index.aspx?DataSetCode=TIVA_2016_C1

Porter, M. E. 1985. Competitive Advantage: Creating and Sustaining Superior Performance. New York: The Free Press.

SVRK. 2015. 'Slovenia Smart Specialization Strategy s4.' http://www.svrk .gov.si/fileadmin/svrk.gov.si/pageuploads/Dokumenti_za_objavo_na _vstopni_strani/S4_document_2015_ENG.pdf

UNIDO. 2004. Inserting Local Industries into Global Value Chains and Global Production Networks: Opportunities and Challanges for Upgrading. Vienna: UNIDO.

UnCTAD. 2007. 'Integrating Developming Countries Smes into Global Value Chains.' Paper for expert meeting on Enhancing the participation of SMEs in Gvcs, Geneva, 18-19 October.

Yi, K.-M. 2003. 'Can Vertical Specialization Explain the Growth of World Trade?' Journal of Political Economy 111 (1): 52-102.

This paper is published under the terms of the Attribution-

NonCommercial-NoDerivatives 4.0 International (CC BY-NC-ND 4.0)

License (http://creativecommons.org/licenses/by-nc-nd/4.o/). 